the satellite was glowing a dull orange, but had developed no tail. At latitudes south of $20^{\circ} \mathrm{N}$. it had a long tail alive with sparks, "like those thrown off from a grinding wheel". The sparks were often seen to fall away from the tail and then soon ceased to glow. Estimates of the length of the tail vary between 30 and 90 nautical miles, with a mean of about 50 nautical miles. The estimates of the brightness suggest that when the satellite was between latitudes $20^{\circ} \mathrm{N}$. and $15^{\circ} \mathrm{N}$. its stellar magnitude was roughly -5 at a distance of 100 nautical miles. The satellite seems to have taken on almost every colour of the spectrum at some time during its descent, and it is only possible to list the colours reported, which were : orange, white, yellow, greenish-blue and red; yellow and orange; orange, silver, blue and green; yellowish-white; blue and red; white to greenish. blue; red and white; green and red; red, orange and white; white; and "a rather sulky crimson".

We wish to thank the captains and crews of the ships from which observations were made. We also thank Mr. D. H. Sadler, superintendent of H.M. Nautical Almanac Office, who arranged for a general call to shipping to be made and sent us the reports received.

\title{
OBITUARIES
}

\section{Dr. W. S. Bauld}

ThE tragic death of Dr. William St. Clair Bauld, his wife Marion, and two of their children on July 20 in a car accident in Canada profoundly shocked and saddened their many close friends in Great Britain.

Bauld was born at Wolfville, Nova Scotia, in 1919. In 1939 he graduated B.A. with honours in chemistry from Acadia University and then proceeded to Dalhousie University, where he was awarded the degree of M.Sc. in 1941 for research on the cestrogens carried out under the direction of the late Dr. R. D. H. Heard. During 1941-43 Bauld served in the Royal Canadian Artillery and was at first on the teaching staff of the Army Radar School, then becoming overseas liaison officer for the Canadian National Research Council and finally officer-incharge of inspection of all radar equipment made in Canada. He retired from the Canadian Army with the rank of major.

After the War, Bauld decided to study medicine and enrolled at McGill University. In 1949 he graduated M.D., C.M. I first met Bauld in Montreal a year before his graduation from McGill and was greatly impressed by his personality and by his evident wish to resume research on the estrogenic hormone. This meeting led to Bauld's appointment to a lectureship in the Department of Biochemistry in the University of Edinburgh in October 1949.

At Edinburgh, Bauld was outstandingly successful both as a teacher and as a research worker. He was a lucid and inspiring lecturer who was very popular with, and respected by, those he taught. His elegant work on the quantitative determination of cestriol, cestrone and oestradiol- $17 \beta$ in urine gained him international recognition as an authority in the field of the oestrogenic hormone, and in 1953 he was awarded the degree of Ph.D. for a thesis embodying the results of this work. A chance observation made by Bauld in the course of this work led to the subsequent isolation by him and me of 16-epiostriol from the urine of pregnant women.

Bauld's contributions to the Edinburgh Medical School were not merely those of a first-class teacher and research worker. His capacity for working hard and playing hard and his infectious enthusiasm for everything he did acted as a tonic to all who came in contact with him. He was greatly missed when he returned to Montreal in $\mathbf{1 9 5 4}$ to join the staff of the Montreal General Hospital as an assistant in the Department of Metabolism and Toxicology.
Bauld's prozress after his return to Montreal was spectacular. At the time of his death, less than four years later, he had become associate director of the Department of Metabolism and Toxicology, assistant director of the Montreal General Hospital McGill University Clinic and assistant professor of medicine at McGill University, and had become recognized as a chemical pathologist of the highest rank.

'The Baulds' home, whether in Edinburgh or in Montreal, was a particularly happy one where visitors were always warmly welcomed. In both cities the Baulds had many friends who loved and respected them and who will miss them sorely.

$$
\text { G. F. Marrian }
$$

\section{Prof. G. M. Wishart}

Prof. G. M. Wishart died on July 18 in his sixtythird year after a short illness. Since 1947 Wishart had devoted himself to administration, being director of postgraduate medical education and dean of the Medical Faculty of the University of Glasgow. Previously Wishart had held the Gardiner chair of physiological chemistry : the later period, given over to administration, has tended to obscure the merit of the scientific work in the earlier years.

The medical profession of to-day accepts with good grace the importance of the basic sciences in the theory and practice of medicine : it was not always so, and men such as Wishart had more than a little to do with this change of heart.

Wishart was instinctively at home in the physical sciences : his first degree was in science: he qualified afterwards in medicine. In the 1920's, biochemistry was applying accurate chemical techniques to biological problems. Wishart studied in Lund under Thunberg and this gave him an abiding interest in the factors governing enzyme action. Hydrogen ion concentration had to be measured accurately because of its importance in biological systems : Wishart designed a glass electrode to measure $p \mathrm{H}$. He early appreciated the potentialities of the thermionic valve and designed a most sensitive electronic oscillometer to measure blood pressure in man.

About this same time the application of indirect calorimetry to man had become well established. It was now possible to measure with accuracy the factors, internal and external, influencing the expenditure of energy in human beings. Wishart made a quite exhaustive study of basal metabolism and 